\title{
Survey on Pathological Lesion and Its Financial Losses in Ovine Slaughtered at Jimma Municipal Abattoir, Jimma, Ethiopia
}

\author{
Mohammed Abatemam, EndegenaTaye, Abu Urji and Dinaol Belina* \\ Department of Veterinary Medicine, Haramaya University, Ethiopia
}

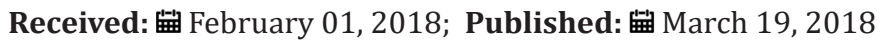

*Corresponding author: Dinaol Belina, College of Veterinary Medicine, Haramaya University, Dire Dawa, Ethiopia

\begin{abstract}
A cross-sectional study was conducted from October 2016 to July 2017 on ovine slaughtered at Jimma municipal abattoir with the aim of identifying main pathological lesions causing organs and carcass condemnation, and associated direct financial losses. In this, 384 sheep were recruited to the study using systematic random sampling and standard antemortem (AM), and postmortem inspection (PMI) procedures were employed. Nasal discharge, tick infestation, coughing, lameness, emaciation, depression and salivation are recorded as the major AM findings of the current study. Accordingly, 47 (12.2\%) sheep showed signs of diseases and abnormalities; of which 23(6\%) were conditionally approved whereas 11 (2.9\%) sheep were unfit and judged to be detained and rejected. In the present study age, body conditions and geographic origin of the animals were considered as study variables, and the results showed BCS and age groups had statistically higher $(\mathrm{p} \leq 0.05)$ rejection probabilities. PM examination findings indicated a total of 192 lesions were encountered, of which 48.9\%, 29.2\%, 6.8\%, and 5.7\% lesions were recorded from livers, lungs, GIT, and hearts and kidneys, respectively. During the PM inspection, both total and partial condemnation judgments were passed on organs and carcass appeared with a sign of abnormality. C. teniculosis 58 (30.2\%), calcification 36(18.7\%), abscess 31(16.2\%), hydatid cyst $23(12 \%)$, hepatitis $10(5.2 \%)$, pericarditis $4(2 \%)$, bruise $3(1.6 \%)$ and nephritis $2(1 \%)$ were found to be the major pathological lesions recorded. In two sheep all organs and carcass were totally condemned as their entire bodies appeared yellowish. The direct loss due to the condemnation of organs and carcasses at Jimma municipal abattoir was also investigated in slaughtered sheep, and there were about 56,576 USD losses per year. In conclusion, this study has identified the pathological lesions affecting edible organs and meat, and then rendering them unfit for human consumption. The study also estimated pathological lesions associated direct financial losses at Jimma abattoir. Therefore, further studies focusing on the primary causes of the abnormalities were recommended in the study area.
\end{abstract}

Keywords: Abattoir; Financial loss; Lesion; Organ condemnation; PMI; Sheep; Jimma

\section{Introduction}

The livestock sector globally is highly dynamic, contributes $40 \%$ of the global value of agricultural output and support the livelihoods and food security of almost a billion people (Thornton [1]). Within African society, small ruminant comprises a greater proportion of the total wealth of the rural families, because of the low input requirements such as low initial capital, fewer resources and maintenance cost. They are also able to produce milk and meat in readily usable quantities using marginal lands and poor pasture and crop residues. Furthermore, their production cycle makes them need only short periods to reconstitute flocks after a disaster and respond quickly to the demand (Getenby, [2]). Ethiopia is the leading African country in livestock population, having around 34-40 million TLU (Tropical livestock unit) out of which 17\% and $12 \%$ cattle and small ruminants, respectively, are found in Ethiopia (Ministry of information (MOI) [3]. According to (Development, pp Statis, [4]), the population of sheep and goats in Ethiopia is estimated to be 26.1 and 21.7 million respectively. It was the third largest number of sheep and goat among African nations and rank eighth in the world (Alemu and Merkel, [5]). 
They generate cash income from export of meat, edible organs, skins and live animals (Ibrahim, 1998). There is also a high domestic meat demand from these animals, particularly during religious festivals. Even though this sub-sector contributes much to the national economy, its development is hampered by various constraints. These include endemic animal diseases, insufficient nutrition, poor husbandry, and lack of sufficient infrastructure, trained labor and government policies (PACE, [6]). Each year a large loss results from the death of animals and weight loss during transportation; and condemnation of edible organs and carcasses at slaughter.

Abattoir meat inspection is essential to remove gross abnormalities from meat and its products, to prevent the distribution of contaminated meat and to assist detecting and eradication of certain livestock diseases. More specifically, antemortem inspection attempts to avoid introduction of clinically diseased animals into slaughter house and also serves to obtain information that will be useful in making sound post mortem inspection. Likewise, postmortem inspection is the center around which meat hygiene revolves since it provides information essential for evaluation of clinical signs and pathological process that affect the wholesomeness of meat (Herenda, et al. [7]).

As the meat is the sources of protein to a human being, it should be clean and free from diseases of particular importance to the public such as tuberculosis and cysticercosis. Meat is also condemned at slaughterhouse to break the chain of some zoonoses which are not transmitted to man directly via meat like hydatidosis and other important diseases of animals such as fasciolosis (Arbabi and Hooshyr [8]; Fufa et al. [9]).

Each year a significant economic loss results from mortality, poor weight gain, condemnation of edible organs and carcasses at slaughter. This production loss in the livestock industry is estimated at more than 900 million USD annually (Jacob, [10]; Abebe, [11]; Jobre et al. [12]). The major causes of pathological lesion during PMI of slaughtered ovine at abattoir are the disease caused by parasites, bacterial and other abnormalities. The final judgment as to action to be taken with an organ, the carcass or part of a carcass is based on the total evidence produced by the visual observation, palpation and incision (Teka, [13]). Abattoir data is an important option for observing the diseases of both economic and public health importance (Arbabi and Hooshyr, [8]; Fufa, et al. [9]). Nowadays, several modern abattoirs like: HELMEX, ELFORA, Metehara, Modjo and Luna are established in Ethiopia. This increase in a number of slaughterhouse shows that increase in demand for meat supply, but the provisions have been challenging due to diseases, production problems and other factors. Given this, proper evaluation of financial losses due to organ condemnation resulting from various diseases at abattoirs is needed (Ezana, [14]). It is necessary to have enough information on a pathological lesion that causes organs and carcass condemnation at the abattoir. Hence, having information on where and how to reduce the losses that may be caused by the various abnormalities (lesions/pathology). Various studies (Jembere, [15]; Yimam, [16]; Aseffa, [17]; Getachew, [18]; Regessa et al. [19]) were carried out in the country in this regard to know the causes and losses associated. However, in Jimma there are no recorded studies conducted on major causes and financial losses associated with organs and carcass condemnation along with survey on pathological lesions. Therefore, the objectives of this study were to:

a) Identify major pathological lesions causing organs and carcass condemnation in slaughtered sheep at Jimma municipal abattoir

b) Estimate the direct financial losses attributed to condemned organs and carcass in sheep

\section{Materials And Methods}

\section{Study Area}

The study was conducted from November 2016 to July 2017 at Jimma municipal abattoir in Jimma zone. Jimma two is found in Oromia region south-western part of Ethiopia at a distance of $346 \mathrm{~km}$ away from Addis Ababa and lies between 3650'E longitude and $7^{\circ} 40^{\prime} \mathrm{N}$ latitude atan average elevation of 1750 meter above sea level. Jimma is the largest city in south-western Ethiopia. It is special zone of the Oromia Regional state and is surrounded by different Jimma woreda. The climate of the area is characterized by humid tropical with bimodal heavy rainfall which is uniform in amount and distribution, ranging from 1200 to $2800 \mathrm{~mm}$ per year, with short and main seasons occurring from mid-February to May and June to September, respectively. The rainy season extends from mid-February to early October. Temperatures at Jimma are in a comfortable range, with the daily mean staying between $20^{\circ} \mathrm{C}$ and $25^{\circ} \mathrm{C}$ year-round. The total human populations of Jimma town was about 174, 446(88, 766 males and 85, 680 females). The livestock population of the area was reported to be about 2,016 , 823cattle, 942, 908 sheep, 288, 411 goats, 74, 574 horses, 49, 489 donkey, 28, 371 mules, 1, 139, 735 poultry and 418,831 bee hives (GOR, [20]).

\section{Study Population}

The study animals were sheep brought Jimma municipal abattoir and destined for slaughter. All animals were male and belonged to indigenous breeds kept under extensive management system. Sheep destined for slaughter had come from different parts of the weredas in the Jimma zone such as Dedo, Serbo, Saqa and Bilida inspected by standard AM, and PMI.

\section{Study Design}

A cross-sectional study using systemic random sampling technique was conducted from December 2016 to April 2017 to determine the pathological lesion that causes organs and carcass condemnation and to estimate the magnitude of direct financial loss attributed in sheep slaughtered at Jimma abattoir. 


\section{Sampling Method}

\section{Sample size determination}

In this study, systematic random sampling method was applied to include study animals, and study animals were grouped into young (under 1year and three months) and adult above this based on the eruption of one or more incisor teeth according to Vatta et al. [21]. Since there was no published work on lesion survey from Jimma abattoir, $50 \%$ expected prevalence is considered to calculate the total sample size with 95\% CI, 5\% level of precision (Thrushfield, [22]). The sample size was 384 and determined using the formula given by

$$
\mathrm{N}=\frac{1.96^{2} \mathrm{P}_{\text {exp }}\left(1-\mathrm{P}_{\text {exp }}\right)}{\mathrm{d}^{2}}
$$

Where $\mathrm{N}=$ required sample size, $\mathrm{P}_{\text {exp }}=$ expected prevalence and $\mathrm{d}$ is desired absolute precision. Accordingly, the total sheep included in the study were 384 .

\section{Abattoir Survey}

In the cross-sectional study of active abattoir survey, both $\mathrm{AM}$ and PMI were carried out in accordance by the procedures of Ethiopian Meat Inspection Regulation (Belina and Melese, [23]).

\section{Ante-mortem Inspection (AMI)}

The AMI (pre-slaughter examinations) of ovine was conducted at lairage both in motion and at rest and information related to study variables such as the behavior of an animal, age, BCS and origin and were recorded. At the same time, various signs of diseases and abnormalities were inspected with physical animal examination and its judgment were approved, conditionally approved, detained and rejected. Study animals were grouped into young and adult age groups according to standard dentation method (Vatta et al.[21]).

\section{Post Mortem inspection (PMI)}

During PMI all internal organs (liver, lungs, heart, kidney, gastro-intestinal tract), and carcasses were thoroughly inspected by visualization, palpation and making systematic incisions for the presence of cysts, parasites and other abnormalities. Pathological lesions were differentiated and judged according to guidelines on meat inspection for developing countries as totally fit for human consumption, and conditionally approved, and totally or partially condemned when unfit for human consumption (FAO, [24]).

\section{Assessment of direct Financial Loss}

In the current study, the total financial loss due to organs and carcass condemnation was computed by considering the condemnation rate or percentage of each edible organ and carcass, average number of animals slaughtered in the abattoir per year from retrospective data of the abattoir. The average weight of each organ and carcasses in $\mathrm{kg}$, average current local market price of major organs and carcass, and each condemned organ was counted to estimate the financial loss. The average current local market price of each organ and mutton was collected by questionnaire from the butcheries in Jimma town for ease of computing the loss

The retail average market prices obtained from butcher shops found in Jimma town in ETB were: Liver=30, lung=20, kidney=15, heart $=18$, GIT=90, whole carcass $=4000$ and mutton $=150 \mathrm{ETB} / \mathrm{kg}$. In the case when there was whole carcass plus organs (whole body) rejection at PM, the average price of sheep came for slaughter was considered (4,000ETB). The direct loss is calculated according to the procedures described by Ogurinade and Ogunrinade [25], and the formula:

$$
\text { Los }=M A K * P L \sum_{i=1}^{i=n}(P i C i), \text { where }
$$

LOS is direct annual financial loss due to organs and carcass loss, MAK is annual average number of sheep slaughtered at Jimma abattoir, PL is overall prevalence of lesion, $\mathrm{P}_{\mathrm{i}}$ is prevalence of each organ and carcass condemned, $\mathrm{C}_{\mathrm{i}}$ is average market price of each organ and $1 \mathrm{~kg}$ mutton at butcher shops of the Jimma town. The direct financial loss was expressed in US Dollar (\$) based on the current currency exchange rate of 1 USD $=22.5$ Ethiopian Birr (ETB).

\section{Data Analysis}

The active abattoir data, and questionnaire survey were entered into Microsoft Excel- 2016 spread sheet and the process of coding, cleaning and validating was done on this sheet and analyzed using SPSS version 20. For the data from PMI, descriptive statistics were used to determine organ and carcass condemnation rates, defined as the proportion of organs and carcasses condemned to the total number of organs and carcasses examined. Each financial loss was also calculated. Possible variation between rejection rates of specific organs, age groups and origin, were taken into consideration.

\section{Results}

\section{Abattoir Survey \\ Antemortem Inspection (AMI)}

Detail AMI was conducted on a total of 384 sheep destined for slaughter at Jimma municipal abattoir and 47 (12.2\%) of ovine were found to have different abnormalities. Nasal discharge, coughing, tick infestation, depression, emaciation, and lameness were those frequently observed among signs of diseases encountered in both age groups. The result also showed 6\% (23/384) animals were conditionally passed for slaughter because of abnormalities such as lameness, respiratory problem, and their collection with tick infestation. On the other hand2\% (8/384) sheep were unfit for human consumption and rejected during AMI. Since, they showed two and more signs of diseases such as emaciation with nasal discharge and depression 1\% (4/384), salivation and salivation with coughing $1 \%(4 / 384)$ were the major cause of rejection (Table 1). 
Table 1: Abnormalities encountered during AM inspection within Age groups and Origin of the animals.

\begin{tabular}{|c|c|c|c|c|c|c|c|c|}
\hline Ante-mortem & Age (\%) & & & Origin (\%) & & & \\
\hline Finding & Adult & Young & Sub Total & Dedo & Bilida & Seka & Serbo & Sub Total \\
\hline Apparently healthy & $171(85.9)$ & $166(89.7)$ & $337(87.8)$ & $127(88)$ & $65(84)$ & $99(89)$ & $46(88.5)$ & $337(87.8)$ \\
\hline Depression & $2(1)$ & $1(0.5)$ & $3(0.8)$ & $2(1.4)$ & $1(1.3)$ & $0(0)$ & $0(0)$ & $3(0.78)$ \\
\hline Salivation & $1(0.5)$ & $1(0.5)$ & $2(0.5)$ & $0(0)$ & $1(1.3)$ & $1(0.9)$ & $0(0)$ & $2(0.5)$ \\
\hline Emaciation and nasal discharge & $1(0.5)$ & $1(0.5)$ & $2(0.5)$ & $1(0.7)$ & $0(0)$ & $0(0)$ & $1(2)$ & $2(0.5)$ \\
\hline Tick infestation and coughing & $2(1)$ & $0(0)$ & $2(0.5)$ & $1(0.7)$ & $0(0)$ & $1(0.9)$ & $0(0)$ & $2(0.5)$ \\
\hline Coughing & $3(1.5)$ & $2(1.1)$ & $5(1.3)$ & $0(0)$ & $1(1.3)$ & $4(3.6)$ & $0(0)$ & $5(1.3)$ \\
\hline Lameness & $3(1.5)$ & $1(0.5)$ & $4(1)$ & $0(0)$ & $2(2.6)$ & $1(0.9)$ & $0(0)$ & $4(1)$ \\
\hline Coughing and salivation & $0(0)$ & $2(1.1)$ & $2(0.5)$ & $0(0)$ & $1(1.3)$ & $1(0.9)$ & $0(0)$ & $2(0.5)$ \\
\hline Tick infestation & $5(2.5)$ & $5(2.7)$ & $10(2.6)$ & $2(1.4)$ & $3(4)$ & $1(0.9)$ & $3(5.8)$ & $10(2.6)$ \\
\hline Emaciation and depression & $1(0.5)$ & $1(0.5)$ & $2(0.5)$ & $2(1.4)$ & $0(0)$ & $0(0)$ & $0(0)$ & $2(0.5)$ \\
\hline Nasal discharge & $10(5)$ & $4(2.2)$ & $14(3.6)$ & $8(5.6)$ & $2(2.6)$ & $2(1.8)$ & $2(3.8)$ & $14(3.6)$ \\
\hline Tick infestation and lameness & $0(0)$ & $1(0.5)$ & $1(0.3)$ & $1(0.7)$ & $0(0)$ & $1(0.9)$ & $0(0)$ & $1(0.26)$ \\
\hline Total & 199 & 185 & 384 & 144 & 77 & 111 & 52 & 384 \\
\hline
\end{tabular}

The AMI result also depicted of 28 sheep with poor body conditions $46.43 \%$ were found to have one or more sign/s of illness whereas in those with good BCS only $7 \%$ of the sheep were showed sign/s of diseases (Graph 1). In the current study, four different decisions were passed as AM judgments where apparently healthy

sheep were passed for slaughter (91\%), and others showed mild sign of illness and conditionally approved (6\%) whereas $2.9 \%$ of sheep were detained and rejected as unfit for slaughter. Rejection rate was significantly higher $(\mathrm{p} \leq 0.05)$ in young animals with poor BCS than in adult animals with good and medium BCS (Table 2).

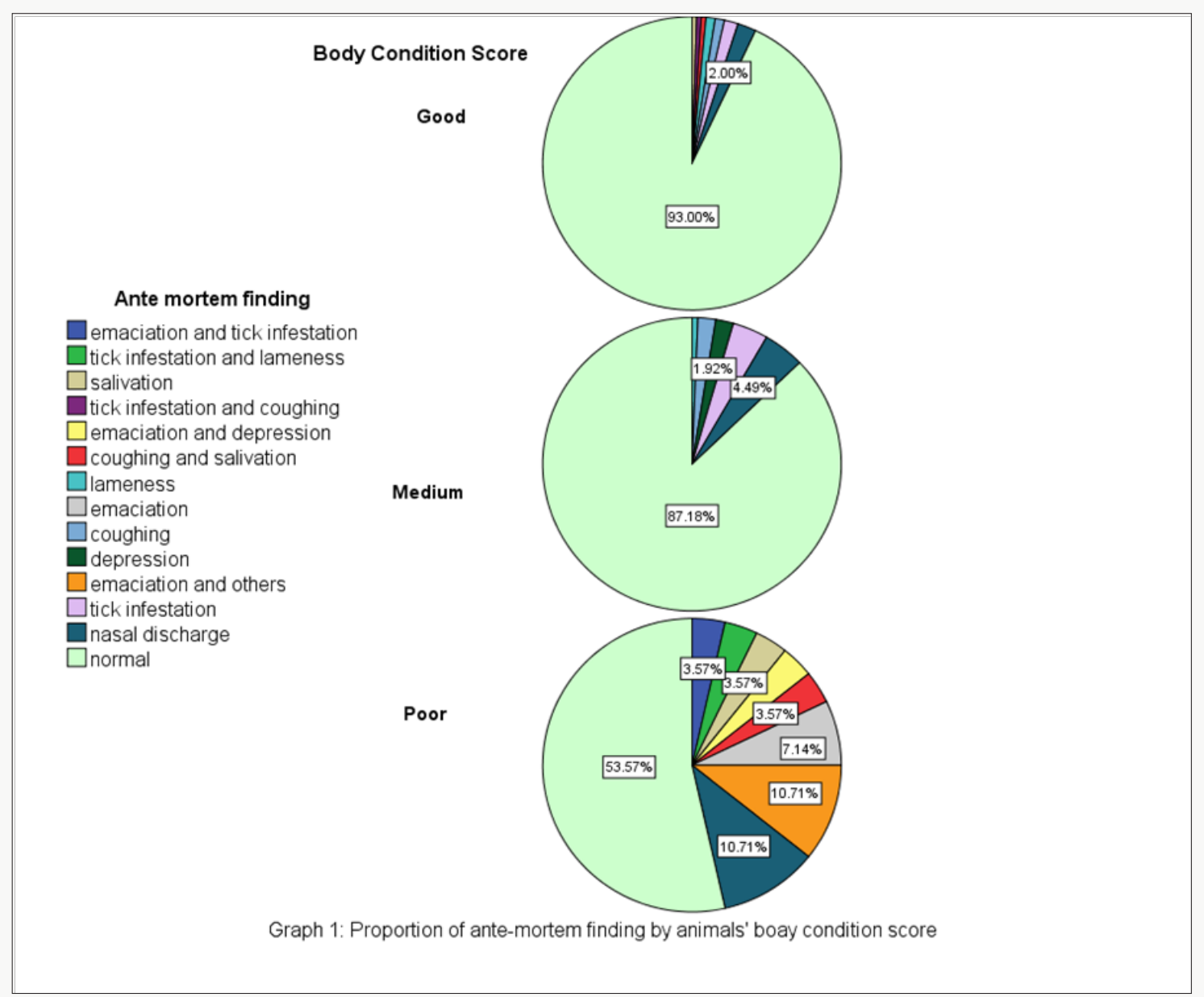

Figure 1: proportion of ante-mortem finding by animals'boay condition score. 
Table 2: Proportion of animals rejected and passed the AMI judgments by age group and BCS at the abattoirs.

\begin{tabular}{|c|c|c|c|c|c|c|}
\hline AMI & \multicolumn{2}{|c|}{ Age (\%) } & \multicolumn{3}{c|}{ Body condition score (\%) } & Subtotal (\%) \\
\hline Judgment & Young & Adult & Good & Medium & Poor & \\
\hline Rejected & $6(3.2)$ & $2(1.0)$ & $2(1.0)$ & 0 & $6(21.4)$ & $8(2)$ \\
\hline Detained & 0 & $4(2.0)$ & 0 & $1(0.64)$ & $3(10.7)$ & $4(1)$ \\
\hline Cond. Approved & $8(4.3)$ & $13(6.5)$ & $10(5)$ & $9(5.8)$ & $4(14.3)$ & $23(6)$ \\
\hline Approved & $171(92.4)$ & $178(89.5)$ & $188(94)$ & $146(93.6)$ & $15(53.6)$ & $349(91)$ \\
\hline Total 185 199 & & & 200 & 156 & 28 & 384 \\
\hline X(P value) & 0.05 & & & & 0.00 & \\
\hline
\end{tabular}

\section{Postmortem Inspection (PMI)}

Among animals that had been examined during AMI 373 were slaughtered and subjected to through PMI following standard postmortem procedure and a total of192gross pathological lesion leading to partial and total condemnation of organs and carcasses were recorded. Among these abnormalities, lesions were frequently encountered from liver; and of which Cyst cercus teniculosis (34\%) and calcification accounted $25.5 \%$. These followed by abscess (13.8\%), hepatitis $(10.6 \%)$, cirrhosis $(7.4 \%)$ and hydatid cyst (7.4\%), fasciolosis (5.3\%) and stelezia hepatica (3.2\%).

Table 3: Relative percentages of pathological lesions resulted in condemnations of organs and or carcasses at the abattoir.

\begin{tabular}{|c|c|c|c|c|c|c|}
\hline \multirow{2}{*}{ Organ affected } & \multirow{2}{*}{ Causes/lesion } & \multicolumn{4}{|c|}{ PMJ (\%) } & \multirow{2}{*}{ P value } \\
\hline & & *AP & PC & TC & Total & \\
\hline \multirow{17}{*}{ Liver } & Teniculosis & 0 & $14(23)$ & $2(1.8)$ & $16(9)$ & \\
\hline & Calcification & $1(16.7)$ & $12(19.8)$ & $3(2.7)$ & $16(9)$ & \\
\hline & Discoloration & 0 & $1(1.6)$ & $3(2.7)$ & $4(2.3)$ & \\
\hline & Hydatid cyst & 0 & 0 & $2(1.8)$ & $2(1.12)$ & \\
\hline & Fasciolosis & 0 & 0 & $3(2.7)$ & $3(1.7)$ & \\
\hline & Cirrhosis & 0 & 0 & $7(6.3)$ & $7(3.9)$ & 0.00 \\
\hline & Abscess & 0 & $1(1.6)$ & $3(2.7)$ & $4(2.3)$ & \\
\hline & Hepatitis & 0 & 0 & $7(6.3)$ & $7(3.9)$ & \\
\hline & Stelezia hepatica & 0 & 0 & $3(2.7)$ & $3(1.7)$ & \\
\hline & Teniculosis and calcification & 0 & $2(3.3)$ & 0 & $2(1.12)$ & \\
\hline & Teniculosis and abscess & 0 & $1(1.6)$ & $1(0.9)$ & $2(1.12)$ & \\
\hline & Teniculosis and hepatitis & 0 & 0 & $1(0.9)$ & $1(0.56)$ & \\
\hline & Calcification and fasciolosis & 0 & 0 & $2(1.8)$ & $2(1.12)$ & \\
\hline & Hepatitis and calcification & 0 & 0 & $1(0.9)$ & $1(0.56)$ & \\
\hline & Abscess and hepatitis & 0 & 0 & $1(0.9)$ & $1(0.56)$ & \\
\hline & Teniculosis and hydatid & 0 & 0 & $1(0.9)$ & $1(0.56)$ & \\
\hline & More than three lesions & 0 & $1(1.6)$ & $2(1.8)$ & $3(1.7)$ & \\
\hline \multirow{12}{*}{ Lung } & Calcification & $1(16.7)$ & $3(4.9)$ & $2(1.8)$ & $6(3.4)$ & \\
\hline & Teniculosis & 0 & $3(4.9)$ & $1(0.9)$ & $4(2.3)$ & \\
\hline & Marbling & 0 & $3(4.9)$ & $6(5.4)$ & $9(5)$ & \\
\hline & Pneumonia & 0 & 0 & $5(4.5)$ & $5(2.8)$ & \\
\hline & Hydatid cyst & 0 & 0 & $5(4.5)$ & $5(2.8)$ & \\
\hline & Emphysema & 0 & $1(1.6)$ & $2(1.8)$ & $3(1.7)$ & \\
\hline & Abscess & 0 & 0 & $1(0.9)$ & $1(0.56)$ & \\
\hline & Emphysema and teniculosis & 0 & 0 & $6(5.4)$ & $6(3.4)$ & \\
\hline & Marbling and teniculosis & 0 & 0 & $1(0.9)$ & $1(0.56)$ & \\
\hline & Teniculosis and pneumonia & 0 & 0 & $2(1.8)$ & $2(1.12)$ & \\
\hline & Hydatid and calcification & 0 & 0 & $1(0.9)$ & $1(0.56)$ & \\
\hline & Unidentified Lesion & $1(16.7)$ & 0 & $2(1.8)$ & $3(1.7)$ & \\
\hline
\end{tabular}




\begin{tabular}{|c|c|c|c|c|c|c|}
\hline \multirow{3}{*}{ Heart } & Discoloration & 0 & 0 & $1(0.9)$ & $1(0.56)$ & 0.00 \\
\hline & Pericarditis & 0 & 0 & $4(3.6)$ & $4(2.3)$ & \\
\hline & hydatid cyst & 0 & 0 & $3(2.7)$ & $3(1.7)$ & \\
\hline \multirow{5}{*}{ Kidney } & Abscess & 0 & $1(1.6)$ & $3(2.7)$ & $4(2.3)$ & \\
\hline & Calcification & $1(16.7)$ & $1(1.6)$ & 0 & $2(1.12)$ & \\
\hline & Nephritis & 0 & $0(0)$ & $2(1.8)$ & $2(1.12)$ & \\
\hline & Discoloration & 0 & 0 & $1(0.9)$ & $1(0.56)$ & \\
\hline & Unidentified & 0 & 0 & $2(1.8)$ & $2(1.12)$ & \\
\hline \multirow{3}{*}{ GIT } & Teniculosis & 0 & $2(3.3)$ & $1(0.9)$ & $3(1.7)$ & \\
\hline & Foreign body & $2(33.3)$ & $2(3.3)$ & 0 & $4(2.3)$ & \\
\hline & Abscess & 0 & $1(1.6)$ & $2(1.8)$ & $3(1.7)$ & \\
\hline \multirow{4}{*}{ Carcass } & Bruise & 0 & $2(3.3)$ & 0 & $2(1.12)$ & \\
\hline & Abscess & 0 & $2(3.3)$ & 0 & $2(1.12)$ & \\
\hline & Hydatid and Bruise & 0 & $1(1.6)$ & 0 & $1(0.56)$ & \\
\hline & Discoloration & 0 & 0 & $2(1.8)$ & $2(1.12)$ & \\
\hline \multirow{2}{*}{ liver and kidney } & Calcification & 0 & $1(1.6)$ & 0 & $1(0.56)$ & \\
\hline & Abscess & 0 & 0 & $2(1.8)$ & $2(1.12)$ & \\
\hline heart and lung & Hydatid cyst and abscess & 0 & 0 & $1(0.9)$ & $1(0.56)$ & \\
\hline lung and kidney & Hydatid cyst & 0 & 0 & $1(0.9)$ & $1(0.56)$ & \\
\hline \multirow{5}{*}{ Liver and Lung } & Calcification & 0 & $1(1.6)$ & 0 & $1(0.56)$ & \\
\hline & Teniculosis & 0 & $3(4.9)$ & $2(1.8)$ & $5(2.8)$ & \\
\hline & Hydatid cyst & 0 & 0 & $1(0.9)$ & $1(0.56)$ & \\
\hline & Hydatid and calcification & 0 & 0 & $1(0.9)$ & $1(0.56)$ & \\
\hline & Teniculosis and hydatid & 0 & 0 & $2(1.8)$ & $2(1.12)$ & \\
\hline \multirow{3}{*}{ Liver and GIT } & Teniculosis & 0 & $2(3.3)$ & 0 & $2(1.12)$ & \\
\hline & Teniculosis and abscess & 0 & 0 & $1(0.9)$ & $1(0.56)$ & \\
\hline & Abscess & 0 & 0 & $1(0.9)$ & $1(0.56)$ & \\
\hline Liver and GIT & Abscess & 0 & 0 & $1(0.9)$ & $1(0.56)$ & \\
\hline Liver and heart & Abscess & 0 & 0 & $2(1.8)$ & $2(1.12)$ & \\
\hline Total & & $6(3.4)$ & 61(99.8) & 111(99.9) & $178(100)$ & \\
\hline
\end{tabular}

*AP=organs conditionally passed for human consumption

A total of 56 lungs were also condemned as they were affected abscess (3.6\%) and 5\% with unidentified lesions. In this study by teniculosis (35.7\%), Hydatid cyst (21.4\%), marbling lesion abscessation was also inspected in other organs like heart, kidney (17.8\%), Emphysema and calcification (16\%), pneumonia (12.5\%), and GIT, and carcass (Table 3).

Table 4: Summary of direct financial losses and organs and carcass condemned at abattoir.

\begin{tabular}{|c|c|c|c|c|c|c|c|}
\hline \multirow{3}{*}{$\begin{array}{l}\text { Condemnation status } \\
\text { PC } \\
\end{array}$} & \multicolumn{7}{|c|}{ Organ condemned } \\
\hline & \multirow{2}{*}{$\begin{array}{c}\text { Liver } \\
39\end{array}$} & \multirow{2}{*}{$\begin{array}{c}\text { GIT } \\
7\end{array}$} & \multirow{2}{*}{$\begin{array}{c}\text { Lung } \\
14\end{array}$} & \multirow{2}{*}{$\begin{array}{c}\text { Heart } \\
0\end{array}$} & \multirow{2}{*}{$\begin{array}{c}\text { Kidney } \\
3\end{array}$} & \multicolumn{2}{|c|}{ Carcass } \\
\hline & & & & & & $5(3 \mathrm{~kg})$ & 68 \\
\hline $\mathrm{TC}$ & 55 & 6 & 42 & 11 & 8 & $2^{*}$ & 124 \\
\hline Total & 94 & 13 & 56 & 11 & 11 & 7 & 192 \\
\hline Price in US \$ & 99.33 & 38 & 43.556 & 8.8 & 6.33 & 37 & \\
\hline
\end{tabular}

There was a condition of examining, a single to multiple lesions per organ e.g., we examined teniculosis and Calcification from a single liver; and all are recorded as different lesions.

* $=$ Whole carcass plus organs totally rejected at PM; except in carcass, PC indicates 50\% loss.

Out of a total of 11 hearts condemned (Table 4), hydatid cyst and pericarditis recorded as major causes contributing $45.5 \%$ and $36.4 \%$ which followed by abscess $(18.2 \%)$ and discoloration $(0.9 \%)$.
Renal problems were observed in 11 kidney examined and $54.5 \%$ found to be caused by abscess whereas $27.3 \%$ and $18.2 \%$ were due to calcification and nephritis and other unidentified causes, 
respectively.13 GITs were also encounter as with abnormalities likecyst cercus teniculosis and abscess and foreign bodies, and they were subjected to total and partial condemnation accordingly.

The major pathological conditions for carcass rejection from local market were bruising accounting for $42.9 \%$. Out of 7 rejections judgments 2 were total and the rest 5 were partial (Table $3 \& 4$ ). There was a condition of examining, a single to multiple lesions per organ e.g., we examined teniculosis and Calcification from a single liver; and all are recorded as different lesions.

*=Whole carcass plus organs totally rejected at PM; except in carcass, PC indicates $50 \%$ loss.

\section{Assessment of Direct Financial Losses}

The direct financial loss was computed based on average cost/ price of individual condemned organs and carcasses during the study period, applying the formula given by Ogurinade and Ogunrinade [25]. The study indicated that there had been a total loss of $12,729,960$ ETB which is 56,576 USD due to a partial and total condemnation of organs and carcass at slaughterhouse annually. The study result also indicated there was a total condemnation of $2(1.3 \%)$ whole carcasses (carcass plus organs) (Table 4). For the calculation, alive price of one sheep is considered as 4000ETB for total carcass condemnation.

\section{Discussions}

The AM and PM inspections were conducted in the abattoir for the purpose of identifying an abnormality and removing animals' products with pathological lesions which were unsafe for human consumption and having poor aesthetic values (Van $\mathrm{L}$ logtestijn, [26]; Gracey et al. [27]). In this research, out of 384 study animals $11(2.9 \%)$ were rejected and detained as unfit for human consumption suspecting different zoonotic diseases such as rabies in the case of salivation with high fever and tuberculosis in animals with a sign of emaciation with high coughing, depression and nasal discharge. Similarly, suspecting rabies in the case of salivation and bovine TB in animals with sign of emaciation with high depression and coughing was reported by Belina and Melese [23]. Radostits et al. [28] stated that in domestic ruminants, cobalt deficiency results in appetence and loss of body weight, emaciation, weakness, decreased growth, unthrifty appearance, diarrhea, and anemia. Again during the AMI, 23(6\%) of sheep were found to be showing signs of abnormalities such as lameness, tick infestation along with coughing and nasal discharge frequently encountered and passed with judgments of conditional approval where due attention was given for whole body part and specific organ at postmortem examinations.

One of the causes of lameness was trauma caused by hitting with a thick stick during driving to abattoir on foot and inappropriate vehicles and loading and off-loading negligence during transportation to marketplaces and to the abattoir. During the AM examinations, it was found that respiratory disorders were higher than other abnormalities encountered during the AMI $14(3.7 \%)$ nasal discharge and $5(1.3 \%)$ coughing. The respiratory signs such as the presence of nasal discharge and coughing were most probably related to stress due to lack of feed and water that may lead to immune suppression enhancing opportunistic pathogens. On the other hand, overcrowding during transportation is also a source of stress (Getachew, [18]). In agreement to the current study, coughing, depression and lameness are frequently observed abnormalities encountered during AMI (Mandefro et al. [29]) at Elfora Export Abattoir, Ethiopia.

The rejection rate was significantly higher $(\mathrm{p}<0.05)$ for those poor body conditions than good and medium body conditions (Table 2). Because of poor BC by itself may be due to unidentified abnormalities that increase rejection probability. Jibat et al. [30] studied and determined the rate of organs and carcasses condemned and the associated annual financial loss at HELMEX abattoir in Ethiopia and they reported out of 2688 sheep and goats examined 188 (7\%) carcasses were condemned due to poor body condition cases.

On the other hand, there was a significant difference $(\mathrm{p}=0.051)$ within the age groups of animals in rejection at AM more young than the adult which were $3.2 \%(6 / 185)$ and $1 \%(2 / 199)$ respectively. It may due to difficulty in protection from stress, shortage of feed and water, not getting enough rest. Herenda et al. [31] stated that leanness (Poorness) is often observed in case of poor quality pasture and young growing animals which have had protein-deficient diet.

In the present study, organ condemnation rate showed that, liver and lung were the most frequently affected organs with the highest condemnation rate followed by GIT, kidney and heart and carcass significantly ( $\mathrm{p}=00)$, which is $94(48.9 \%), 56(29.2 \%)$, $13(6.8 \%), 11(5.7 \%), 11(5.7 \%)$ and $7(3.6 \%)$ respectively. This finding is in agreement with reports of Cadmus and Adesokan [32] who recorded that lungs (45.7\%) and the liver $(32.9 \%)$ were the most affected organs with the kidney $(0.02 \%)$ and the heart $(0.01 \%)$ being the least. The current study introduced that parasites are the major causes of organ condemnations. Parasitic causes like, Cyst cercus teniculosis, hydatidosis, fasciolosis and Stelezia hepatica were found to be the major parasitic conditions responsible for organ condemnation. There was no statistical difference in the rate of organ and carcass condemnation from parasitic infestation considering the age and origin of animals. This shows that parasitic diseases of sheep are widely spread in all age groups and everywhere in the country.

The presence of small ruminant hydatidosis at slaughterhouse has been documented in Ethiopia. (Bekele et al., [33]) reported a prevalence rate of $16.4 \%$ in sheep which is higher than the finding in this study (7.4\%). Similarly (Jobre et al. [12]) reported prevalence rate of $11 \%$ and $6 \%$ from South Omo and Debrezeit slaughterhouses, respectively in sheep and goats. In present finding, hydatid cysts were more frequently observed in lungs 
than liver of sheep (6.3\%) and (3.6\%) respectively. Additionally, similar findings were also reported by different authors (Khan et al. [34], Dalimai et al. [35] and Daryani et al. [36]). However, the most common site for hydatid cyst was the liver followed by the lungs in the Middle East (Kamhawi et al. [37]). Lungs are most commonly affected by hydatidosis because at old age the liver capillaries are dilated, and most cysts passed directly to the lung. Secondly, the cyst passes to the lung via the thoracic duct without involving the liver (Gracey, [38]). And also, many researchers reported that liver and lung are the most commonly affected organs by hydatid cyst (Abunna and Hordofa, [39]; Denbarga, [40]; Jobre, [12]). The reason being that lung and liver contain highest capillary bed in the body and therefore, the majority of the oncospheres were filtered out and trapped in the fine blood capillaries and only small number of oncospheres reaches the remaining organs (Gracey, [38]). In present study also lungs and liver 12(6.3\%) and 7(3.6\%) respectively, were affected by hydatidosis.

Out of 94 condemned liver teniculosis is the most frequent cause of organ lesion (34\%) followed by calcification (25.5\%), abscess $13(13.8 \%)$, hepatitis $10(10.6 \%)$, cirrhosis $7(7.4 \%)$, discoloration $4(4.3 \%)$, more than 3 lesion on liver $3(3.2 \%)$ and parasites like teniculosis, Stelezia hepatica, Fasciola species and hydatid cyst were found to be the major causes that rendered liver rejection from the local market (Table 3). Fascioliasis constitutes both economic and public health constrains to ruminant production. It is caused by two trematode species, Fasciola hepatica and F.gigantica, which develop in different livestock species mainly sheep and cattle; but, also in many other domestic herbivores (Gracey, and Collins, [41]). The reported prevalence of Fasciolaspp. (5.3\%) was lower than other studies in bovine, like Belina and Melese [23] study result showed fasciolosis and hydatidosis alone contributed $690(35.1 \%)$ gross pathological lesions.

Previous studies have indicated a higher economic loss resulting from a condemnation of edible organs and carcasses due to parasitic causes (Negategize et al. [42]; Jembere, [15]; Jibat, [43]). In the current study, these parasitic causes of liver lesion might be due to improper wasting of condemned organ and the stray dog feed it at abattoir and selling of infected offal for dog which is final host for teniculosis and hydatidosis and stay them. Sissay et al. [44] studied the prevalence and seasonal incidence of cestodeparasite infections of sheep in Eastern Ethiopia for two years (2003-2005). During this period, viscera including liver, lungs, heart, kidneys and the gastro-intestinal tract were collected from 655 sheep slaughtered at four abattoirs. One of the most prevalent metacestodes was C. teniculosis. In sheep, the overall prevalence was $79 \%$ for C.teniculosis.

The causes for calcification abscess, hepatitis, cirrhosis and discoloration were difficult to identify grossly and it may be due to systemic infectious diseases. Calcification is also another lesion that we encountered; it can be caused by injury, infection, and autoimmune disorders. Large-scale tissue damage is associated with extensive loss of cells, a situation referred to as tissue necrosis. The death of tissue in a specific area of the body leads to the release of signaling factors that attracts cells to clean up and heals the dead tissue. This process, known as an inflammatory response, attracts calcium into the damaged area as it heals (Carne, [45]). This study indicates $24(12.5 \%), 9(4.7 \%)$ and $3(1.6 \%)$ of Liver, lung, and kidney, respectively were affected by calcification.

Abscess was also apathological condition; which is a collection of pus circumscribed by fibrous tissues. It occurs with great frequency throughout many organs and the carcasses of the meat animals and may be associated with a general condition or be found as isolated lesions (Libby, [46]). In present study $13(6.8 \%)$, $6(3.1 \%), 6(3.1 \%), 2(1 \%)$ and $2(1 \%)$ of liver, GIT, kidney, heart and carcass were affected by abscess. In agreement with (FSIS, [47]) stated that caseous lymphadenitis is a disease of sheep and goats caused by the C.Pseudotuberculosis. Postmortem findings may include, enlarged abscessed lymph nodes with greenish whiteyellow caseous exudate, which tends to become dry and granular, cross-sections of lesions contain remnants of connective tissue capsules (resembles the concentric rings seen on the cut surface of an onion). Lesions found in many lymph nodes, especially the subiliac, superficial cervical, deep popliteal, tracheobronchial, and mediastinal lymph nodes, as well as lungs, heart, liver, spleen, and kidneys. (Asrat, [48]) stated that occasionally the worms penetrate the bile duct wall into the liver parenchyma causing liver abscesses.

The study conducted in Gondar abattoir (Mesele et al. [49]) and Nekemte (Moje et al. [50]) also revealed that livers and lungs are the most rejected organs by PM inspection and fasciolosis and hydatidosis are the major causes of rejections. However, in the current study different calcifications, cirrhosis, hepatitis, abscessations, emphysema, pneumonic lesions, marbling (contagious caprine pleuropneumonia (CСP)) lesion, nephritis, foreign body, traumatic lesions and others non parasitic abnormalities and unidentified lesion contributed to a condemnation of organs and carcasses were investigated. Lungs were condemned because of C.teniculosis, hydatid cysts, marbling, emphysema, calcification, pneumonia, other unknown caused lesion and abscess which were (35.7\%), (21.4\%), (17.8\%),(16\%), (16\%), (12.5\%), (5\%) and (3.6\%) respectively. C.teniculosis accounts for $35.7 \%$ as a principal cause of lung condemnation in sheep This might because of increased number of a stray dog in the area, the principal cause of lung condemnation was parasitic. However, the report observed during a retrospective study (Regassa et al., [19]) reported pneumonia as a principal cause of lung condemnation in central Ethiopia accounting for $42.1 \%$ (Getachew, [18]). In current study, from the total lungs inspected higher 56 (29.2\%) lungs were condemned. It may because of the animals unable to resist stress within a short period of time during transportation along way on foot, shortage of feed and water, stress due to hitting of animal by personnel who driving animal to market from the farmer and to abattoir and does not getting sufficient amount of rest at lairage may causes this respiratory problem. 
FSIS [47] reported that pneumonia is an inflammatory condition of the lungs that maybe caused by infectious agents, parasites, physical trauma, or foreign material inhalation. In similar reports pneumonia might also be as a result of endemic diseases of sheep and goats such as pasteurellosis, which is triggered by stress, contagious caprine pleuropneumonia (Radiostitis et al. [51]). The other cause was marbled appearance (CCPP) lesions: CCPP is a disease peculiar to shoat and takes the form of a chronic inflammation of the lungs and pleura. It is not communicable to man and the carcass and the lungs found to be positive for CCPP can be passed for human consumption after a partial condemnation of the diseased part Gracey and Collins [41]. On the other hand, Emphysema is an abnormal and permanent enlargement of air spaces distal to terminal bronchioles with destruction of their alveolar walls, whereas oedema is a nonspecific lesion in which interstitium and alveoli are accumulated with fluid (Carne, [45]).

Also, different lesions of infectious and noninfectious causes like abscess, pericarditis, nephritis, and discoloration were found to be important causes for the condemnation of edible organs like liver, heart, and kidney. Similarly the same causes were found at central Ethiopia (Getachew, [18]; Regassa et al. [19]) and in goats slaughtered at Nigeria (Ojo, [52]).

In the present study, out of the $11(5.7 \%)$ kidneys condemned abscess 6 (54.5\%) account, whereas calcification accounts $3(27.2 \%)$, nephritis $2(18.2 \%)$ and other unidentified causes $2(18.2 \%)$ (Table 3$)$. In this study abscess was a principal cause of kidney condemnation, however, the result in (Dejene et al. [53]) study revealed out of the 57 (6.71\%) kidneys condemned Nephritis $20(2.35 \%)$ accounting for $11(2.59 \%)$ and 9 (2.12\%) kidneys in Ovine and Caprine respectively, was the principal cause of condemnation. Radostitis et al., [28] stated that embolic nephritis occurs after septicemia or bacteremia when bacteria lodge in renal tissue.

The major causes of heart condemnation were found to be pericarditis, hydatid cyst and abscess. Out of the total of 11 (5.7\%) hearts condemned due to gross abnormalities, pericarditis contributes about $4(36.4 \%)$ and hydatid cyst also contribute $4(36.4 \%)$ and abscess $3(27.3 \%)$ out of condemned organs (Table $3)$. The main cause of lesion in GIT condemnation primarily parasitic C.teniculosis and abscess $6(46.2 \%)$ and foreign body $4(30.8 \%)$. As a septic lesion, whenever localized abscess is found, partial condemnation is recommended Gracey and Collins [41].

The main management practices that rendered organs and carcasses unfit for human consumption were bruising of the carcass mainly brought about by not proper handling of animals during transportation to the slaughterhouses by hitting the animal with thick stick and mechanical damage to organs due to faulty evisceration especially liver. Apart from affecting carcass value, bruising has also animal welfare implications as excessive use of sticks while driving to the abattoir, mishandling of animals during loading and unloading, improper transport vehicle and at slaughter could be responsible causes (Mungube et al. [54]). It is stated that bruising of animals during transport is the major source of economic loss in Africa and Asia (Mitchell and slough, [25]). In the present study out of 7 carcass condemnations, 2 (28.6\%) whole carcass was also totally condemned due to the yellowish discoloration, suspecting liver disease which may toxicity, systemic disease causing prehepatic and hepatic jaundice. Herenda et al. (2000) stated that icterus is the result of an abnormal accumulation of bile pigment, bilirubin, or of hemoglobin in the blood. Jaundice is divided into three main categories. Prehepatic jaundice occurs following an excessive destruction of red blood cells. Tick-borne diseases such as Babesiaovis and Anaplasmosis cause this type of icterus. Hepatic jaundice occurs due to direct damage to liver cells as seen in liver cirrhosis, systemic infections, and in chemical and plant poisoning. In sheep, jaundice may have been caused by phytogenic chronic copper poisoning. Obstructive jaundice occurs when the drainage of the bile pigment bilirubin is blocked from entry into the intestine.

However, parasitic C.teniculosis and Stelezia hepatic have no public health importance; they are considered as the important cause of economic loss in the meat industry since viscera harboring them are rejected for aesthetic reasons. The threat these parasites pose to small ruminants' meat industry in Ethiopia is evident due to the present situation of improper disposal of offal at abattoirs and backyard slaughter. The presence of freely roaming stray dogs on grazing land together with livestock and the deeply-rooted habit of feeding dogs with offal, including sheep heads, are important risk factors. This may lead to the perpetuation of the life cycle between intermediate hosts (sheep) and the final hosts (dogs) for C.teniculosis and hydatidosis.

The financial loss in the abattoir was high, in this study analyzed those losses through condemnation of organs and carcass from local market. A total loss of (56,576 USD USD) was incurred in the abattoir. Carcass condemnation accounts highest part of the losses of the total direct losses whereas liver, lung, GIT, heart and kidney takes, respectively. The indirect losses from body weight gain, mortality at the farms, public health implications (cause of treatment for a human when diseased upon eating of the affected edible organ which is zoonotic) were not included in the analysis in this study. Thus, the total financial loss attributable to diseases of ovine and, hence, abattoir wastage could be much higher. The economic analysis of livestock diseases in Ethiopia is scarce and inadequate because of lack of information on the prevalence and partly by the complexity of the analysis. Negategize et al. [42] have reported a financial loss associated with a liver condemnation due to ovine fasciolosis alone in the central highlands of Ethiopia amounting to be 2.3 million Ethiopian Birr (460,000 USD). Similarly Jobre et al. [12] have estimated a total annual loss of 1.3 million Ethiopian Birr (260000 USD) resulting from offal condemnation and carcass weight loss [55,56]. 


\section{Conclusion And Recommendations}

The currentstudy revealed that, during the study period different signs of diseases, and abnormalities leading to conditional approval, rejection and detain of animals were encountered at AM inspection. In lesion survey, a total of 192 gross pathological lesions resulting in partial and total condemnations of liver, lung, kidney, heart, GIT and carcass were investigated. Different calcifications, parasitic teniculosis, hydatidosis, fasciolosis, Stelezia hepatica, pneumonic lesions, abscess, cirrhosis, marbling (CCPP), emphysema, hepatitis, nephritis, pericarditis, bruising (mechanical damage), discoloration and foreign body were the main abnormalities recorded as causes of (56,576 USD) losses. There is perpetuation of the life cycle between intermediate hosts (sheep) and the final hosts (dogs) for C. teniculosis and hydatidosis by wasting the condemned organ near abattoir; and sometimes selling of affected organ. The results of the study showed that teniculosis and calcification were the two most frequently examined conditions, contributing 58(30.2\%) of gross pathological lesions $[57,58]$.

Based on this conclusion, the following recommendations are recommended:

a) Awareness should be created for the animal attendants, farmers, customers, abattoir workers and butchers regarding the public health significance of diseases of animal origin and the related losses.

b) The government must empower veterinarians and other meat inspector more in passing professional judgments and, avoid complains of investors working in meat industry sector on inspectors judgments.

c) Immediate, safe and controlled elimination of all condemned abattoir materials and the sale of contaminated.

\section{References}

1. Thornton P (2010) Livestock production: recent trends, future prospects. Royal Soc 365(1554): 2853-2867.

2. Gatenby RM 1991 Sheep. The tropical agriculturalist. MACMILLAN, ACCT. pp. 6-10.London and Basingstoke, education Ltd.

3. (2005) Ministry of information (MOI), Export products of Ethiopia. Press release of Ministry of information, department of press and Audio visual. Addis Ababa, Ethiopia.

4. (2009) Central Statistical Authority Federal Democratic Republic of Ethiopia Agricultural Samples Enumeration Statistical Abstract Development Statistical Agency (CSA). Central The Federal Democratic Republic of Ethiopia Pp 446-539.

5. Alemu Y, MerkelR C (2008) Sheep and Goat Production Handbook for Ethiopia: Ethiopia Sheep and Goat Productivity Improvement Program / ESGPIP/ Ministry of Agriculture and Rural 15-53.

6. (2003) Experiences and the way forward on community Based animal health service delivery in Ethiopia. PACE-Ethiopia p. 6.

7. Herenda D, Chambers PG, Ettriqui A, Seneviratnap P, Dasilvat TJP (1994) Manual on meat Inspection for developing countries pp: 139-148.

8. Arbabi M, Hooshyr H 2006 Survey of Regions might have accounted for variation of the Echinococcosis and Hydatidosis in Kashan Region,
Prevalence in different areas of a country Central Iran. Iran J Public Health 35(1): 75-81.

9. Fufa A, Loma A, Bekele M, Alemayehu R (2010) Bovine fasciolosis: coprological, abattoir survey and its economic impact due to liver condemnation at Sodo Municipal abattoir, Southern Ethiopia. Trop Anim Health Prod 42: 289-292.

10. Jacob L, (1979) Seminar for animal health officials. Ministry of agriculture and settlement, Animals and Fisheries authority. Addis Ababa, Ethiopia.

11. Abebe, G ILRI, Addis Ababa (1995) In: Proceeding of an international conference of Current status of veterinary education and health research in Ethiopia In Veterinary Medicine impact on health and nutrition in Africa pp: 133-138.

12. Jobre Y, Lebago F, Tiruneh R, Abebe G, Dorchies (1996) Hydatidosis in their selected regions in Ethiopia: an assessment trail on its prevalence, economic and public health importance. Rev Med Vet 147: 797-804.

13. Teka G (1997) Meat hygiene. In: Food hygiene principles and methods of food born disease control with special reference to Ethiopia pp: 99-113.

14. Ezana G (2007) Major disease of export oriented livestock in export abattoirs in/around adalibenwereda, Debreseit, Ethiopia.

15. Jembere S (2002) A Survey of Causes of Organs/Carcass Condemnation in Slaughtered Cattle at Nazareth Abattoir. Unpublished DVM Thesis, Faculty of Veterinary Medicine, Addis Ababa University, DebreZeit.

16. Yimam M (2003) Major Causes of Organ Condemnation in Ruminants Slaughtered at Gondar Abattoir, North West Ethiopia. Unpublished DVM Thesis, Faculty of Veterinary Medicine, Addis Ababa University, Debrezeit, Ethopia.

17. Aseffa M 2005 Parasitic Causes of Carcass/Organ Condemnation at Asella Municipality Abattoir. Unpublished DVM Thesis, Faculty of Veterinary Medicine, Addis Ababa University, Debrezeit, Ethiopia.

18. Getachew EW (2008) Major Diseases of Export Oriented Livestock in Export Abattoirs in/Around Ada Liben Woreda, Debrezeit. Online DVM Thesis, Faculty of Veterinary Medicine, Haramaya University, Ethiopia.

19. Regassa A, Moje N, Megersaa B, Beyene D, Sheferaw D, et al. (2013) Major causes of organs and carcass condemnation in small ruminants slaughtered at Luna Export Abattoir, Oromia Regional State, Ethiopia. Preventive Veterinary Medicine 110: 139-148.

20. (2006) GOR (Government of Oromia), Oromia reginal government socioeconomic profile. Government of Oromia Region. Addis Ababa, Ethiopia.

21. Vatta AF, Gumede SA, Harrison LJS, Krecek RC, Letty BA, et al. (2005) Goat keepers Veterinary Manual. Onder stepoort Veterinary Institute, Private Bag Onderstepoort, Soutfrica. Veterinary Research 6: 42.

22. Thrushfield M (2007) Veterinary Epidemiology. In: Blackwell Science Ltd $3^{\text {rd }}$ edn. Pp. 244-245, 249-251.

23. Belina D, Melese M 2017 Pathological lesion survey and financial losses associated with organs and carcass condemnation in cattle slaughtered at selected abattoirs in Ethiopia. Indian J Vet Pathol 41(1): 1-11.

24. FAO (1993) Agro State Data. Statistical Division, Rome, Italy.

25. Mitchell JR, Slough CAB (1980) Helminthes in meat inspection. In: Guide to meat inspection in tropics: Common Wealth Agricultural Burro 56-62.

26. Van lontestijn JG (1993) integrated quality Meat safety: A new approach. Meats Focus International 2: 123-128.

27. Gracey JF, Collins DS, Huey RJ (1999) Meat hygiene. 10 ${ }^{\text {th }}$ Edn. Pp.758. In: London. WB Sounders Company Ltd.

28. Radostits O, Gay C, Blood D, Hinchcliff K (2000) Veterinary Medicine. A textbook of the diseases of cattle, sheep, pigs, goats and horses $9^{\text {th }}$ edn. pp. 1877.

29. Mandefro A, Aragaw K, Hailu B, Alemayehu G, Chala G (2015) Major Cause of Organ and Carcass Condemnation and Its Financial Loss at 
Bishoftu Elfora Export Abattoir. International Journal of Nutrition and Food Sciences 4: 364-372.

30. Jibat T, Ejeta G, Asafw Y, Wudie A (2008) Causes of abattoir condemnation in apparently healthy slaughtered sheep and goats at HELMEX abattoir, DebreZeit, Ethiopia. Rev. Méd. Vét., 159(5): 305-311

31. Herenda D, Chambers P, Ettriqui A, Seneviratna P, da Silva T (2000) Manual on meat inspection for developing countries. FAO Anim. Prod .health 119 .

32. Cadmus SIB, Adesokan HK 2009 Causes and implications of bovine organs/offal condemnations in some abattoirs in Western Nigeria. Trop Anim Health Prod 41(7): 1455-1463.

33. Bekele T, Mukassa ME, Kasali OB 1988 The prevalence of cysticercosis and Hydatidosis in Ethiopian sheep. Vet Parasitol 28(3): 267-270.

34. Khan AH, El Buni AA, Ali MY (2001) Fertility of the Cyst of EchinococcusGranulosus in Domestic Herbiivorse from Benghazi, Libya, and the Ractivityof Antigens Produced from them. Ann Trop Med Parasitol 95: 337-342.

35. Dalimi A, Motamedi G, Hosseini M, Mohammadian B, Malaki H, et al (2002) Echinococcosis/hydatidosis in western Iran. Vet Parasitol 105(2): 161-171.

36. Daryani A, Alaei R, Arab R, Sharif M, Dehghan MH, et al. (2007) The Prevalence, Intensity and Viability of Hdatidcysts in Slaughtered Animals in the Ardavil Province Northwest Iran. J Helminthol 81(1): 13-17.

37. Kamhawi S, Hijjawi N, Abu Ghazaleh A, Abbas M (1995) Prevalence of Hydatid Cyst in Livestock from Five Regions in Jorda .Ann Trop Med Hyg 147: 797-804.

38. Gracey JF (1986) Meat Hygiene $8^{\text {th }}$ edn pp.119- 350. In: Baillier Tindall. London.

39. Abunna F, Hordofa D 2013 Major Causes of Organ Condemnation for Cattle and its Financial Impact at Wolaita Soddo Municipality Abattoir Southern Ethiopia. Global Veterinaria 11(6): 730-734.

40. Denbarga Y, Demewez G, Sheferaw D (2011) Major Causes of Organ Condemnation and Financial Significance of Cattle Slaughtered at Gondar Elfora Abattoir, Northern Ethiopia. Global Veterinaria 7(5): 487490.

41. Gracey JF, Collins DS (1992) Meat Hygiene $9^{\text {th }}$ edn pp.339-421. In: Baillier Tindall. London.

42. Negategize PK, Tekleye B, Getachew J (1993) Financial losses caused by ovine fasiolosis in Ethiopian highlands. Trop Anim Hlth Prod 23: 155161.

43. Jibat T (2006) Causes of Organ and Carcass Condemnation in small ruminants slaughtered at HELMEX Abattoir. DVM Thesis, Faculty of Veterinary Medicine, Addis Ababa University, Debrezeit, Ethiopia p. 9-11.

44. Sissay M, Uggla A, Waller P (2008) Prevalence and seasonal incidence of larval and adult cestode infections of sheep and goats in eastern Ethiopia. Trop Anim Hlth Prod 40(6): 387-94.
45. Carne HR 2010 Veterinary pathology hand book. Integrated Cased Based Applied Pathology. Vets 3011.

46. Libby JA (1975) Meat Hygiene. $4^{\text {th }}$ edn. In:Lea and Febiger, pp. 40-168, Philadelphia.

47. FSIS (2009) Public Veterinarian Training USDA FSIS Center for Learning Multi-speci Disposition Basics with a Public Health Focus 1/29/09.

48. Asrat M 2004 Infection prevalence of ovine fasciolosis in irrigation schemes along the Upper Awash River Basin and effects of strategic anthelmintic treatment in selected upstream areas, Addis Ababa University School of Graduate Studies, Department of Biology. M Biomed Sci.

49. Mesele G, Guadu T, Bogale B, Chanie M (2012) Pathological Conditions Causing Organ and Carcass Condemnation and Their Financial Losses in Cattle slaughtered in Gondar, Northwest Ethiopia. Afr J Basic ApplSci 4: 200-208.

50. Moje N, Abdeta D, Kebede S, Terfa T, Desissa F, et al. (2014) Major Causes of Organs and Carcass Condemnation in Cattle Slaughtered at Nekemte Municipality Abattoir, East Wollega, Ethiopia. Global Veterinaria 13(3): 278-284.

51. Radiostitis OM, Gay CC, Hincheliff KW, Constable PD (2007) Veterinary Medicine. A text book of the disease of cattle, horse, sheep, pigs, and goats. $10^{\text {th }}$ edn. Pp. 391-517.

52. Ojo S (1992) A Survey of Pathological Conditions in the Slaughter Goats In: Zaria Slaughterhouse. Faculty of Veterinary Medicine, Ahmadu Bello University p. 1-4.

53. Dejene S, Abebe B, Degefu H (2013) Study on the Major Health Problems That Causes Carcass and Organs Condemnation at Hashim's Export Abattoir, Debrezeit, Ethiopia Global Veterinaria 11(4): 362-371.

54. Mungube EO, Bauni SM, Tenhagen BA, Wamae LW, Nginyi JM, et al (2006) The prevalence and economic significance of Fasciolagigantica and Stilesia hepatica in slaughtered animals in the semi-arid coastal Kenya. Trop Anim Hlth Prod 38(6): 475-483.

55. (1972) Ethiopian Ministry of Agriculture Meat Inspection Regulations (EMAMIR), Legal Notice No. 428 Negarite Gazexa. Addis Ababa, Ethiopia.

56. Ibrahim H (1998) Small Ruminant Production Techniques. pp:207 ILRI Manual 3. ILRI (International Livestock Research Institute), Nairobi, Kenya.

57. Jibat T, Ejeta G, Asafw Y, Wudie A (2008) Causes of abattoir condemnation in apparently healthy slaughtered sheep and goats at HELMEX abattoir, DebreZeit, Ethiopia. Rev. Méd. Vét., 159(5): 305-311.

58. Negategize PKJ, Bekele T, Tilahun G (1993) Financial losses caused by ovine fasciolosis in the Ethiopian highlands. Trop Anim Health Prod 25: $155-161$. 
This work is licensed under Creative Commons Attribution 4.0 License

Submission Link:

Submit Article

DOI: 10.32474/CDVS.2018.01.000101

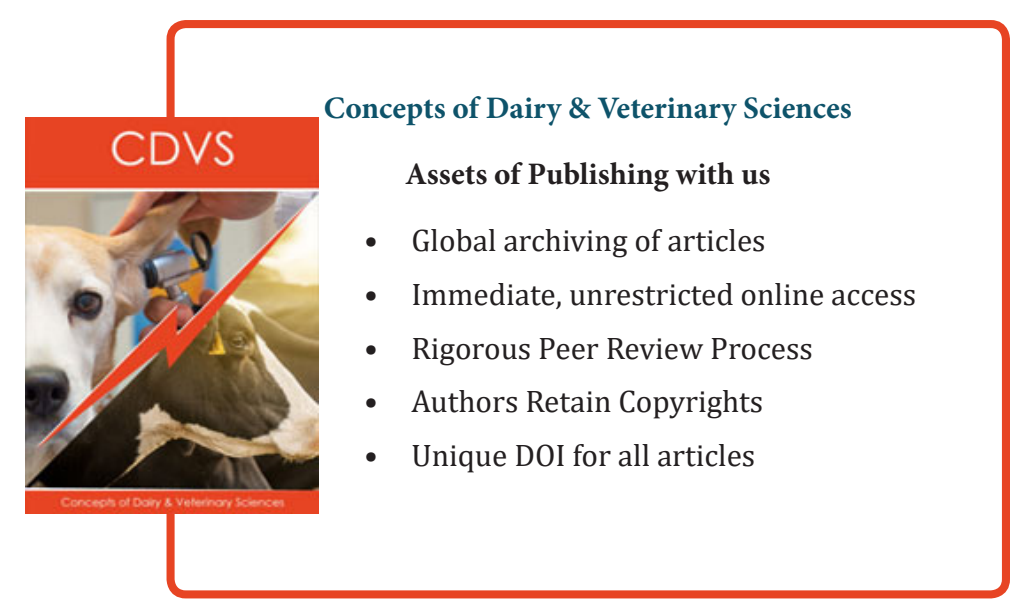

